International Journal of Environment, Agriculture and Biotechnology
Vol-6, Issue-6; Nov-Dec, 2021
JJEAB
Journal Home Page Available: https://ijeab.com/
Journal DOI: $10.22161 /$ ijeab

\title{
Socio-economic impact of cassava wastewater on some communities in Benue State, Nigeria
}

\author{
Onyeke Ochu Linda ${ }^{1}$, Amuta Elizabeth $^{2}$, Aguoru Celestine ${ }^{3}$
}

\author{
${ }^{1,3}$ Department of Botany, University of Agriculture, Makurdi, Nigeria \\ ${ }^{2}$ Department of Zoology, University of Agriculture, Makurdi, Nigeria
}

Received: 20 Jun 2020; Received in revised form: 11 Sep 2021; Accepted: 18 Nov 2021; Available online: 24 Nov 2021

(C)2021 The Author(s). Published by Infogain Publication. This is an open access article under the CC BY license

(https://creativecommons.org/licenses/by/4.0/).

\begin{abstract}
The socio-economic impact of cassava wastewater on some communities in Okpokwu and Ohimini Local Government Areas of Benue State, Nigeria were investigated. These communities are known for high rate of garri production in the State.Twenty structural questionnaires were administered on 293 residents within the study area. A large number (>80\%) of the respondents in the community affirmed that garri wastewater had an offensive odour, changed soil colour, attracted mosquitoes and inhibited plant growth. The study revealed that a large number of the processor may not possess an in-depth knowledge on the effect of the cassava wastewater on the human health and environment at large. Environmental sanitation agencies may carry out routine inspection of processing areas as well as educate the processors of the hazards associated cassava wastewater.
\end{abstract}

Keywords-socio-economic, cassava wastewater, environment, practises, benue.

\section{INTRODUCTION}

1.1 Background to the Study

Nigeria is currently the world's largest producer of cassava accounting for about a fifth of the world's cassava production. It is followed by Thailand (the largest in Asia), Indonesia, Brazil, Ghana, Congo and others [10]; [18]. Consequently, out of the thirty-six (36) states in Nigeria, 24 states produce cassava and Benue State which is acronym the "food basket of the nation", is one of the states with the highest production of cassava [20];[3]. Cassava processing as an industry caters for $30 \%$ of the nation's informal sector in terms of employment and revenue [14]. In developing countries such as Nigeria, about $70 \%$ of harvested cassava roots are processed into garri. This is mostly done by small-scale processors with the aid of simple equipment for cassava processing. However, the traditional method of processing cassava into garri produces a large amount of waste [14]. Till date, several areas in Benue state that are known for the high rate of production of garri, carry out the traditional method of processing garri which incurs a lot of waste. Most individuals in the rural areas use part of their residence or a designated area for the cassava processing and are most times self-employed .Therefore, they produce and move their produce to the available market for sale. Cassava effluents are derived from the dewatering stage as shown in Plate 1 and accounts for about $16 \%$ of total cassava weight [7]. [3] reported an increase in the quantity of cassava produced in Nigeria in recent times due to many initiatives and support programmes. Therefore, an increase in waste production is also expected which may result in environmental pollution when it is not properly managed [16].Also, the establishment of cassava processing centres is an on-going process of the government in Nigeria [2]. Such centres have been sighted in Okpokwu Local Government area of Benue State. However, policies or guidelines for the disposal or treatment of cassava wastewater is lacking [13];[16] and [19]. This study is aimed at assessing the socio-economic impact of cassava wastewater on communities in the study area.

\subsection{Cassava wastewater (Effluent)}

Methods used for processing cassava produce solid and liquid wastes that contaminate the environment [12]. When processing cassava, the peel and liquid effluent squeezed out of the fermented parenchyma mash are the two important biological wastes that may cause damage to the 
environment. Most times the peels are discarded on the soil or water as waste and allowed to rot in the area as well as the liquid effluent which contains a lot of microorganisms [12]. At times homes around an area may discharge fermented cassava wastewater in small volumes. However, for several community individuals undergoing the same practice of fermentation could lead to a massive pollution on the receiving waters [15]. Cassava waste water have in suspended solids about $15,000 \mathrm{mg} / \mathrm{L}$ which are most times not treated but disposed freely into the environment, contaminating nearby water sources in the process. These effluents possess serious environmental impacts causing acidification due to the hydrolysis of cassava cyanogenic glucoside, linamarin and lotaustralin (Methyl linamarin) producing hydrogen cyanide which is also toxic to household animals, fisheries and other organisms [14]. [17] reported that Adult female catfish, Clarias gariepinus showed signs of gill and liver damage as a result of exposure to cassava effluent. Also stated was the histopathological examination carried out on the gill, kidney and liver of fingerlings of the Nile Tilapia (Oreochromis noliticus) that was treated with cassava effluent indicated damage as well. In Allium cepa root meristem, cassava wastewater causes anomalies in cell division process and chromosome aberration induction that could be as a result of heavy metal-cyanide interaction in cassava waste water [17]. Also, the study by [8] concluded that cassava wastewater alters the physicochemical characteristics of soils.

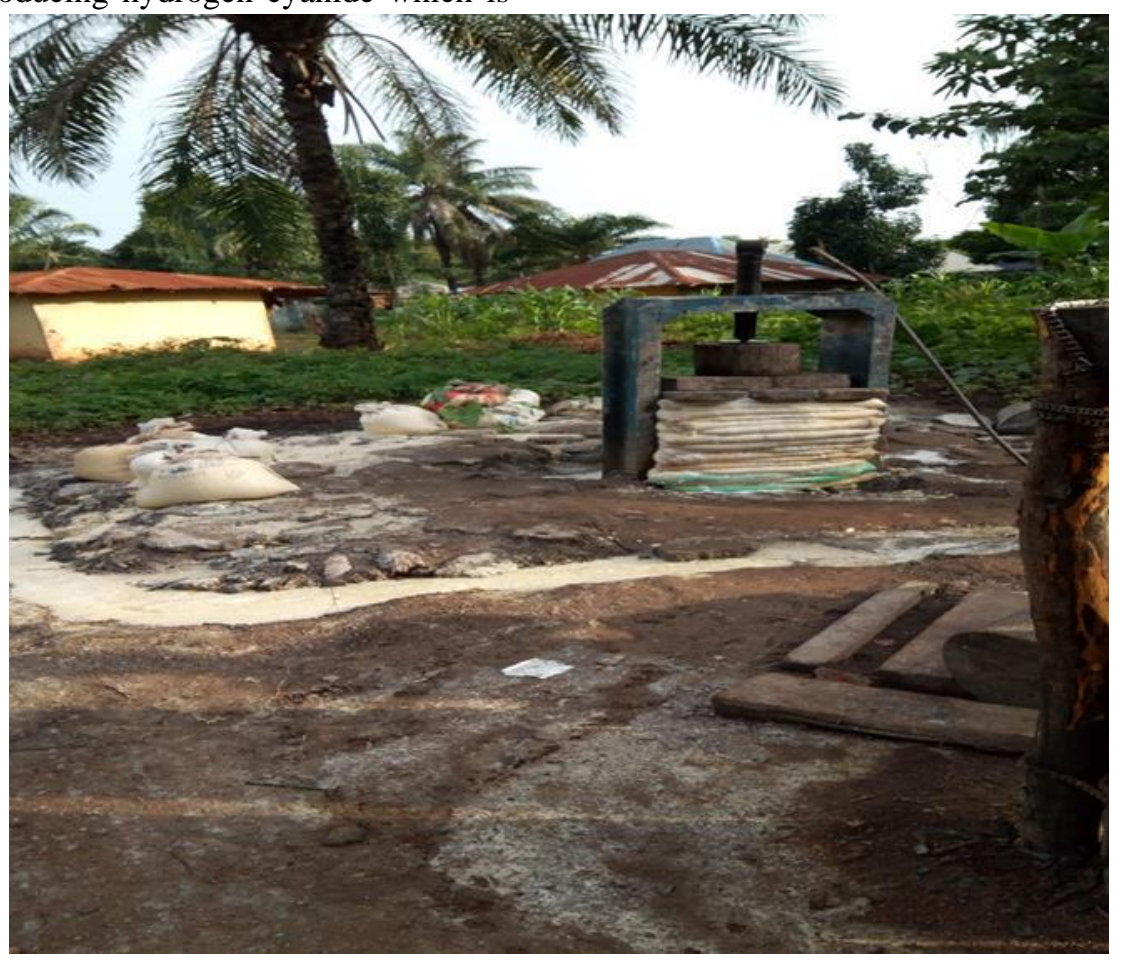

Plate 1: The dewatering stage of cassava processing that produces cassava effluent.

\section{METHODOLOGY}

Study area and sampling procedure

Benue State of Nigeria is located between latitude $7^{\circ} 43^{\prime} 50^{\prime \prime} \mathrm{N}$ and longitude $8^{\circ} 32^{\prime} 10^{\prime \prime} \mathrm{E}$. Its vegetation cover consists of the Southern guinea savannah, with rainfall averages of $1,200-1,500 \mathrm{~mm}$, high relative humidity and fertile soil [11]. It comprises of twenty-three Local government Areas and farming is the common practice of the people with major crops such as yam, Soy beans, sesame, cassava, oil palm, mangoes, oranges, plantain and sweet potatoes cultivated seasonally. These elements contribute immensely as to why the state is termed the Food Basket of the Nation.
Judgmental/selective sampling was used to pick two local government areas namely; Okpokwu and Ohimini based on the high production rate of garri in these areas of Benue State. Collection of information on the socio-economic impact of cassava wastewater on inhabitants in the study area was done using structured questionnaire adopted from Godson-Ibeji and Chikaire (2016). 293 questionnaires were used for the final analysis.

\section{RESULTS}

Estimation method 
The selected variables for this study comprised the sociodemographic data, Attitude and Practices of respondents, Environmental factors and Health factors affecting respondents. A complete description of these variables are given in Table 1, 2 and 3 respectively.

Table 1: Socio-demographic data, attitudes and practices of respondents $(n=293)$.

\begin{tabular}{|c|c|c|c|}
\hline Socio-demographic data & Percentage $(\%)$ & Method used for Garri frying & \\
\hline Gender & & Firewood & 100 \\
\hline Male & 69 & Kerosene & 0 \\
\hline Female & 31 & Gas & 0 \\
\hline Age & & Others & 0 \\
\hline $15-29$ & 52 & Age of garri factory & \\
\hline $30-54$ & 38 & $1-4$ years & 31 \\
\hline $55+$ & 10 & $5-10$ years & 39 \\
\hline Education & & $10+$ years & 30 \\
\hline No formal education & 10 & $\begin{array}{l}\text { Offensive odour } \quad \text { of } \\
\text { surroundings Present }\end{array}$ & \\
\hline Primary & 19 & Yes & 88 \\
\hline Secondary & 47 & No & 12 \\
\hline $\begin{array}{l}\text { Tertiary } \\
\text { Ition }\end{array}$ & 24 & $\begin{array}{l}\text { Colour change of soil where } \\
\text { cassava is pressed }\end{array}$ & \\
\hline Farming & 28 & Yes & 96 \\
\hline Garri processor & 56 & No & 4 \\
\hline Civil servant & 10 & Insects present in & \\
\hline Others & 6 & surrounding of the factory & \\
\hline Attitude and Practices & & Mosquito & 87 \\
\hline Quantity of bags Pressed weekly & & Tsetse fly & 5 \\
\hline $1-5$ bags & 34 & Bug & 8 \\
\hline $5-10$ bags & 18 & Disposal of cassava peel & \\
\hline 11 bags and above & 48 & Burn & 9 \\
\hline Nature of press & & Drop in refuse dump & 86 \\
\hline Wooden & 37 & Do not throw away & 3 \\
\hline Hydraulic jack & 63 & Others & 2 \\
\hline Number of workers & & Disposal of cassava wastewater & \\
\hline $1-5$ & 87 & Allow to flow on the ground & 44 \\
\hline 6 and above & 13 & Collect in a container & 13 \\
\hline Use of cassava waste & & Others & 43 \\
\hline Animal feed & 48 & Do plants grow & \\
\hline Starch & 3 & contaminated soils & \\
\hline Fertilizer & 15 & Yes & 11 \\
\hline No usage of peel & 14 & No & 89 \\
\hline
\end{tabular}

No usage of wastewater 20

Table 2: Environmental factors affecting respondents $(n=293)$.

Environmental factors $\quad$ Percentage (\%)

\section{Method used for Garri frying}

respondents


Table 3: Health factors affecting respondents $(n=293)$

\begin{tabular}{|c|c|}
\hline Health factors & Percentage (\%) \\
\hline \multicolumn{2}{|l|}{$\begin{array}{l}\text { How often do you treat } \\
\text { malaria }\end{array}$} \\
\hline Weekly & 3.8 \\
\hline Monthly & 31.7 \\
\hline Quarterly & 35.5 \\
\hline Yearly & 20.1 \\
\hline None of the above & 8.9 \\
\hline $\begin{array}{l}\text { Dizziness when } \\
\text { processing }\end{array}$ & \\
\hline Yes & 46 \\
\hline No & 54 \\
\hline \multicolumn{2}{|l|}{ Nausea } \\
\hline Yes & 27 \\
\hline No & 73 \\
\hline \multicolumn{2}{|l|}{ Difficulty in breathing } \\
\hline Yes & 41 \\
\hline No & 59 \\
\hline \multicolumn{2}{|l|}{ Headaches } \\
\hline Yes & 60 \\
\hline No & 40 \\
\hline \multicolumn{2}{|l|}{$\begin{array}{l}\text { Ever consumed the } \\
\text { wastewater }\end{array}$} \\
\hline Yes & 4 \\
\hline No & 96 \\
\hline
\end{tabular}

The socio-demographic data, attitude and practice of respondents in the study area are shown in Table 1. The proportion of male to female that carryout garri processing was $69 \%$ to $31 \%$. The age range $15-29$ years which was the youngest had $52 \%$ while $30-54$ years had $38 \%$ and 55 years and above had 10\%. $47 \%$ of garri processors had a secondary school education, $24 \%$ had a tertiary education and $19 \%$ had a primary school education. $10 \%$ had no formal education as shown in fig. 1. Most individuals combined other jobs with garri processing. Occupations of respondents in the study include Garri processing (56\%), Farming (28\%), Civil servant (10\%) and others like students and traders $(6 \%)$. Quantity of bags pressed weekly include, 11 bags and above (48\%), 1-5bags (34\%) and $6-$ 10 bags $(18 \%)$. Two nature of jack were used to squeeze out water from cassava mash. Hydraulic jack (63\%) and wooden jack (37\%). 1-5 number of workers had $87 \%$ while 6 and above number of workers had 13\% indicating that it is a small scale business. $48 \%$ of respondents used cassava waste as animal feed, $3 \%$ used them as starch and $15 \%$ used them as fertilizers. $14 \%$ had no use for the peel while $20 \%$ had no use for the wastewater as shown in Fig. 2. Environmental factors affecting respondents are shown in Table 2. $100 \%$ of respondents used firewood to fry garri. The age of garri factory were as follows, $31 \%$ of respondent's factory were 1-4 years old, $39 \%$ were $5-10$ years old and $30 \%$ were 10 years an above years old. This shows the length of time soils around such areas have been recieving the cassava wastewater. $88 \%$ of respondents agreed that cassava wastewater emits offensive odour while $12 \%$ disagreed. $96 \%$ of respondents agreed that there was a colour change in soils receiving cassava wastewater while $4 \%$ disagreed. $11 \%$ of respondents agreed that plants grow in soils contaminated with cassava wastewater while 89\% disagreed as shown in Fig. 3. Insects present around the factory include mosquitoes (87\%), flies (5\%) and bugs $(8 \%) .86 \%$ of respondents disposal their cassava peel by dropping them in the refuse dump, $9 \%$ burn them , $3 \%$ do not throw them away and $2 \%$ had other use for them like using it in their farmlands to cover the roots of trees. $44 \%$ of respondents dispose of their wastewater by allowing it to flow on the ground, $13 \%$ collect in containers and $43 \%$ had other ways of disposing it like digging trenches for the water to flow away from the area. Health factors affecting respondents are shown in Table 3. 35.5\% of respondent agreed that they treat malaria quarterly, $31.7 \%$ agreed to monthly treatment, $20.1 \%$ agreed to yearly treatment, 3.8 agreed to weekly treatment and $8.9 \%$ stated none of the above. Respondents agreed and disagreed to the following health conditions during processing as shown in Fig. 4. Dizziness, $46 \%$ agreed while $54 \%$ disagreed. $27 \%$ agreed to feel nauseous while $73 \%$ disagreed. $41 \%$ agreed to have difficulty in breathing while 59\% disagreed. $60 \%$ agreed to have headaches while $40 \%$ disagreed. 


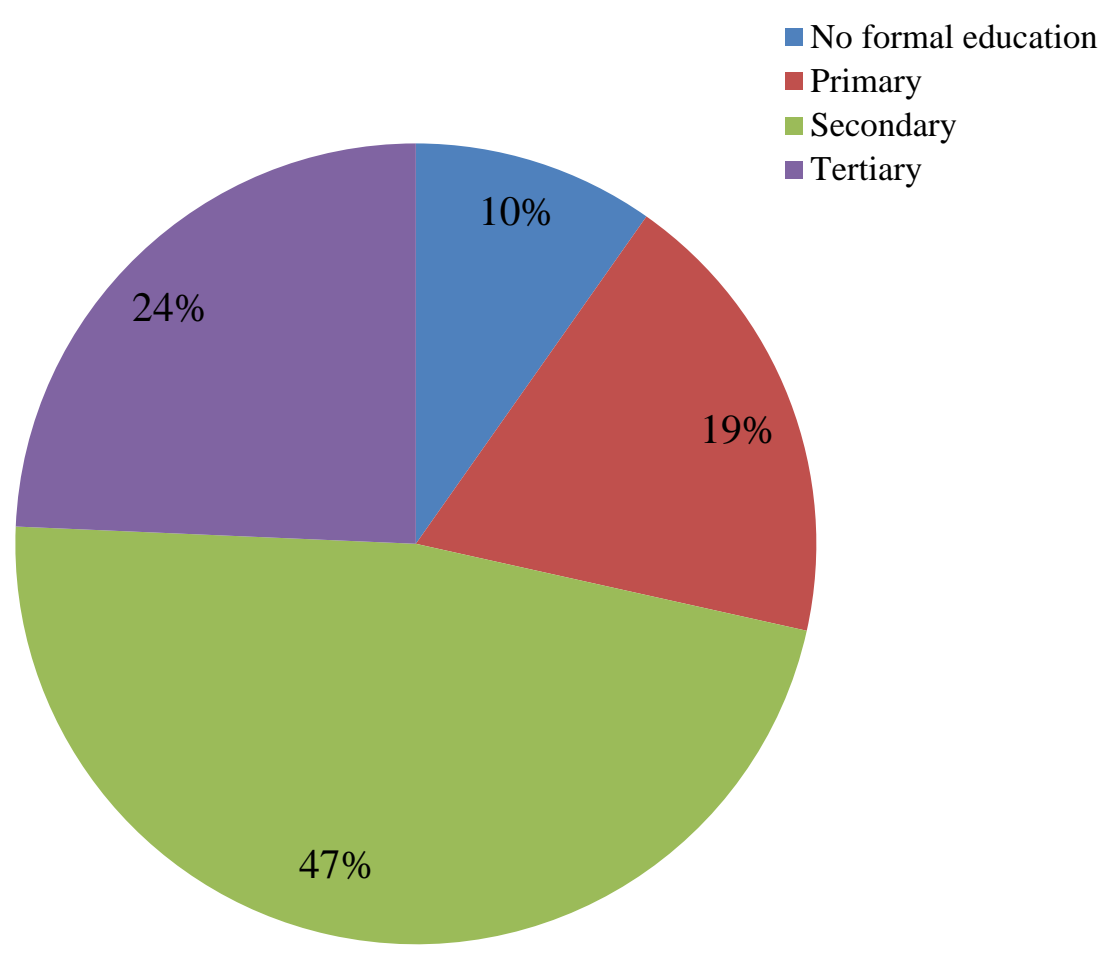

Fig.1: Education of Respondents in the Study Area.

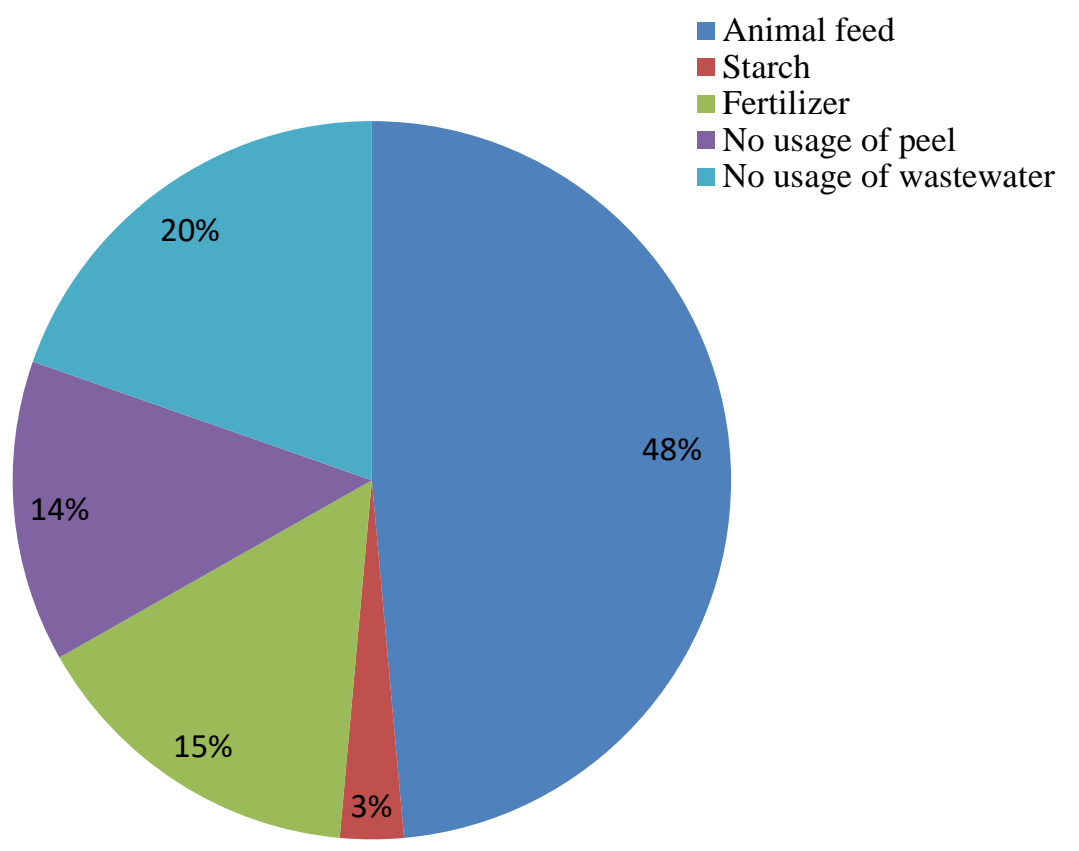

Fig.3: Use of Cassava Waste by Respondents in the Study Area. 


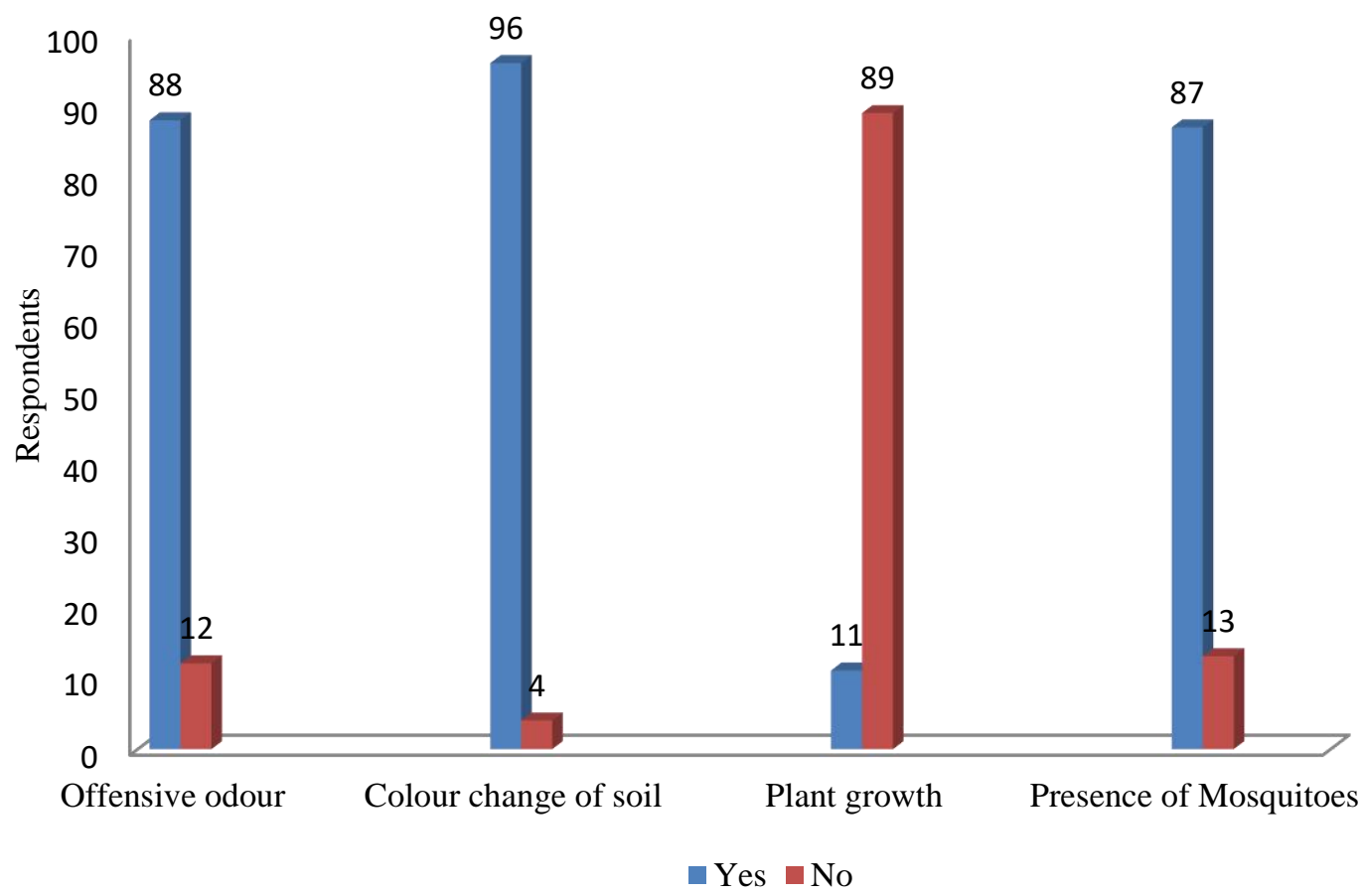

Fig. 3: Responses on the Effect of Cassava Wastes on Communities

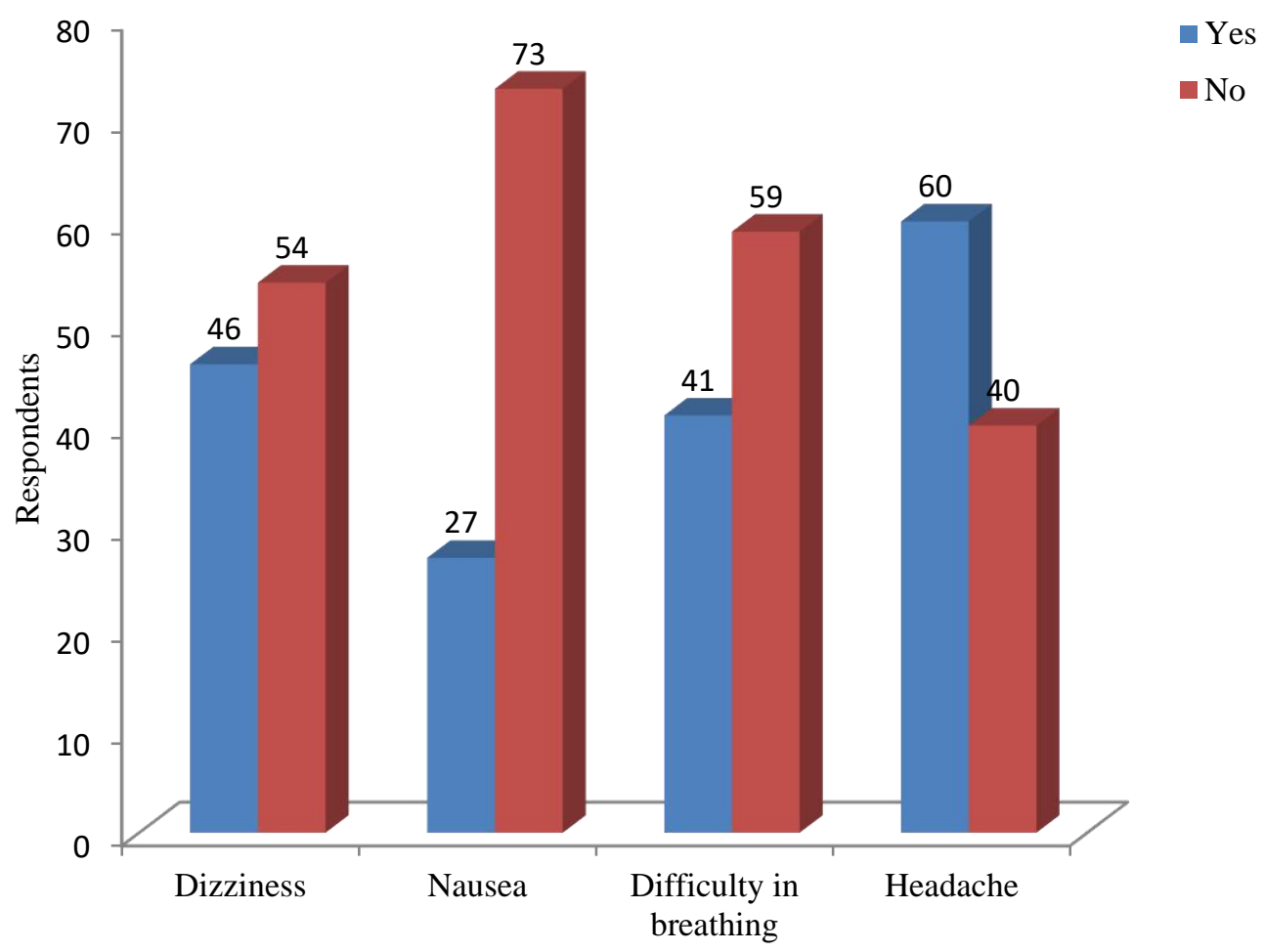

Fig. 4: Some Health Challenges Experienced by Garri Processor 


\section{DISCUSSION}

The socio-economic impact of the cassava wastewater on communities in the study area is shown in the pie chart diagrams. The gender pie chart reveals the male individuals dominating the females in cassava processing business. This could be attributed to the amount of strength needed to jack (dewater) the cassava flasks prior to frying. The hydraulic press in most of the sites need manual labour to work and this action is carried out by the male individuals. The age $15-29$ showed the highest respondent. This indicates that the younger individuals participate more in this business due to the strenuous activities involved. Also, Respondents with secondary school education had the highest percentage (47\%) and is consistent with work done by [16]. Lack of funds restricts most of them from getting a higher qualification therefore they engage themselves in the business for survival and creation of wealth. However, Individuals at this stage of education may not have an in-depth knowledge on the effect of the wastewater on the environment. A lot of respondent indicated garri processor as their occupation showing a high level of participation of individuals in the profession at the study area. Others who engage in other occupations also process garri at the side. 11 bags and above of cassava was pressed weekly which had the highest respondents indicates that most processors press large quantities of cassava weekly thereby leading to an increase in the amount of wastewater generated that eventually flows on the soil which contaminates it. The hydraulic press had the highest percentage and most times operated by the male individuals since it involves the use of strength. It is safer than the wooden press which collapses when the wood begin to rot or not tied properly. All respondents agreed to the use of firewood for the frying of garri. [4] also revealed that firewood was the main heating source for cassava processing communities in Ghana. Firewood is gotten from fell down trees which are chopped into smaller pieces. Thus the survey exposes the dependency of the rural dwellers on firewood as well as the concern of climate change that comes with this activity. The $10+$ year old factory had the least percentage. This is due to a shift in the position of the jack or presses when the soil can longer retain water or begins to cake. The press is then shifted to a new area on the soil. $84 \%$ of respondents indicated that their surrounding had an offensive smell. This agrees with the research by[1] which states that the discharge of the cassava mill waste results in offensive odour originating from the biodegraded products of the waste. Also,[9] reports that its degradation is fast and spreads offensive odour in the environment. Majority $(>90 \%)$ of respondents indicated a colour change in the soil where the cassava is pressed. Thus indicating that cassava wastewater alters the colour of the soil during processing. A lot of the respondents also indicated that they had never consumed the cassava wastewater. Majority attributed their decision to its offensive odour as well as the knowledge of it being poisonous or injurious to health. On the method of cassava waste disposal, this work agrees with the work by [16] where $90.5 \%$ of respondent dump their cassava waste in waste dump site. Also Majortiy (>80\%) of respondent allow their wastewater to flow on the soil thereby contaminating the area. Dizziness, nausea, difficulty in breathing and headaches are associated with the inhalation of hydrogen cyanide gas [6]. However, only few respondents agreed that they experience these symptoms. Residents of the study area also faced the following challenges. Complaint from neighbours of seepage of wastewater into their well-water, poor road network and transportation of their goods out of the area, frequent malfunctioning of the jack and difficulty in squeezing out water from cassava especially when it contains a lot of starch, all jobs are done manually and it is labour intensive.

\section{CONCLUSION}

Majority of the processor were secondary school certificate holders who may not be have an in-depth knowledge on the effect of the cassava wastewater on the human health and environment at large.

A central area for cassava processing should be built in communities that majorly cultivate as well as process cassava products to avoid indiscriminate cassava waste disposal.

Environmental sanitation agencies may carry out routine inspection of processing areas as well as educate the processors of the hazards associated with the discharge of the wastewater directly into the environment.

Processing areas should be subject to public health regulations whereby such areas must comply with the necessary regulations to avoid termination.

Routine spraying of insecticides in the area should be encouraged to destroy breeding areas for disease causes insects

Also, the wastewater generated during processing should be collected in ponds and treated before disposal or reuse

\section{REFERENCES}

[1] Agwaranze, D.I, Nwugo, V.O, Ogodo, A.C., Onudibia, M.E., Nwaneri, C.B. and Aliba N.V. (2018). Effects of cassava mill effluent (CME) on bacteria diversity of soil and aquatic environments in South- South Nigeria. MedCrave Open Acess Journal of Science, 2(4): 238 - 242. 
[2] Akpan, J.F., Eyong, M.O. and Isong, I.A. (2017). The Impact of Long-term Cassava Mill Effluent Discharge on Soil $\mathrm{pH}$ and Microbial Characteristics in Cross River State. Asian Journal of Soil Science and Plant Nutrition, 2(1): 1-9.

[3] Bankole, E. (2018, December 28). Discover the Leaders of Cassava Production In Nigeria. Legit. Retrieved April 25, 2019, from https://www.legit.ng/1208794-cassavaproduction-nigeria-by-state.html

[4] Francis, K., Ahmad, A. and Lawrence, D. (2015). Technical and Socioeconomic Potential of Biogas from Cassava Waste in Ghana. Biotechnology Research International, Vol. 2015, Article ID 828576, 10pp. Retrieved on April 25, 2019, from https://doi.org/10.1155/2015/828576.

[5] Godson-ibeji, C. C. and Chikaire, U. J. (2016). Consequences of Environmental Pollution on Agricultural Productivity in Developing Countries: A Case of Nigeria. International Journal of Agricultural and Food Research, $5(3): 1-12$

[6] Goetz, C.G. (2010). Cyanides. In: Encyclopedia of Movement Disorders. Science Direct. 269-271

[7] Izah, S.C., Bassey, S. E. and Ohimain, E. I. (2017). Assessment of Heavy Metals in Cassava Mill Effluents Contaminated Soil in a Rural Community in the Niger Delta Region of Nigeria”. EC Pharmacology and Toxicology, 4(5): 186-201.

[8] Izonfuo,W., Bariweni, P., and George, D.M.C. (2013). Soil Contamination from Cassava Wastewater Discharges in a Rural Community in the Niger Delta, Nigeria. Journal of Applied Science and Environmental Management, 17 (1): $105-110$.

[9] Jideofor, M.I.(2015). Chemical Adjustment of Effluent from Cassava Processing Plant prior to Safe Disposal. Nigerian Journal of Technology (NIJOTECH), 34 (4):883 - 889.

[10] Mara, S. M. D., Mário, M. R., Anamaria de Sousa, D., Ênio Farias de França de Silva, Elvira, M. R. P., \& Daniel da Costa, D. (2014). Chemical Attributes of Soil Fertilized with Cassava Mill Wastewater and Cultivated with Sunflower.The Scientific World Journal, 2014:1-10.

[11] Nnamonu, L.A and Eli, A.E. (2013). Perception of Agrochemical Use and Organic Farming in Makurdi, Benue State. International Journal of Environmental Protection, 3(8):48-52.

[12] Obueh, H.O. and Odesiri-Eruteyan, E. (2016). A Study on the Effects of Cassava Processing Wastes on the Soil Environment of a Local Cassava Mill. Journal of Pollution Effects and Control, 4(4): 177.

[13] Okunade, D.A. and Adekalu, K.O. (2014). Characterization of Cassava-waste Contaminated Soils in Ile-Ife, Nigeria. European International Journal of Science and Technology, 3(4): $173-182$

[14] Oladele, P.K. (2014). Cassava Processing and the Environmental Effect. The $4^{\text {th }}$ World sustainability Forum 2014. Conference Proceedings Paper.

[15] Olukanni, D.O., Agunwamba, J.C. and Abalogu, R.U. (2013). Interaction between Suspended and Settled Solid Particles in Cassava Wastewater. Academic Journals: Scientific Research and Essays, 8(10):414-424.
[16] Olukanmi, D.O. and Olatunji, T.O. (2018). Cassava Waste Management and Biogas Generation Potential in Selected Local Government Areas in Ogun State, Nigeria. Recycling, 3(58):1-12.

[17] Omotosho, O. and Amori, A. (2015). Caustic Hydrogen Peroxide Treatment of Effluent from Cassava Processing Industry: Prospects and Limitations. International Journal of Engineering and Technology Innovation, 5: 75-85.

[18] Research and Markets (2019, February 21). Global Cassava Processing Market Report 2019: Industry Trends, Shares, Size, Growth, Opportunity and Forecasts 2011-2018 \& 2019-2024. GlobeNewswire. Retrieved on April 25, 2019, from www.globenewswire.com

[19] Ukaegbu-Obi, K.M., Appeh, O.G., Itaman, O.V. and Nwosu, P.C (2018). Microbial and Physicochemical analyses of Soil Receiving Cassava Mill Wastewater in Umudike,Abia State, Nigeria. Nigerian Journal of Biotechnology, 35 (2):99 - 107.

[20] Wossen,T., Tessema, G., Abdoulaye, T., Rabbi, I., Olanrewaju, A.,Alene, A.,Feleke,S., Kulakow, P.,Asumugha, G., Abass, A. and Manyong, V. (2017). The Cassava Monitoring Survey in Nigeria Final Report. International Institute of Tropical Agriculture (IITA), Ibadan, Nigeria. 